\title{
Efektifitas Konseling Online Pada Mahasiswa Selama Pandemi Covid-19
}

\section{The Effectiveness of Online Counselling to Students During Covid-19 Pandemic}

\author{
Nursan Junita( $\left.{ }^{(*)}\right)$ \& Liza Adyani(2) \\ Program Studi Psikologi, Fakultas Kedokteran, Universitas Malikussaleh, Indonesia \\ Disubmit: 01 Desember 2020; Diproses: 31 Maret 2021; Diaccept: 01 September 2021; Dipublish: 02 Desember 2021 \\ *Corresponding author: E-mail: nursan@unimal.ac.id
}

\begin{abstract}
Abstrak
Konseling menjadi salah satu solusi menghadapi stres selama pandemi Covid -19. Konseling merupakan proses yang dapat membantu individu mengatasi berbagai hambatan perkembangan diri. Konseling online merupakan layanan kesehatan mental yang dapat membantu mengurangi kecemasan dan kebingungan semasa pandemik covid-19, dimana aturan sosial dan physical distancing diberlakukan. Tujuan penelitian ini untuk melihat bagaimana efektifitas konseling online selama pandemi covid-19 pada mahasiswa, dengan metode kualitiatif dan pendekatan eksploratif. Responden penelitian terdiri dari 9 mahasiswa yang mengalami kecemasan selama pandemic Covid-19. Hasil penelitian menunjukan bahwa konseling online sangat efektif karena membantu menurunkan kecemasan dan kekhawatiran yang muncul. Semua klien merasakan perubahan yang lebih baik secara kognitif, perilaku dan emosi walaupun tidak melakukan konseling secara tatap muka. Setelah sesi konseling semua klien merasa lebih lega, lebih tenang, kecemasan dan kekhawatiran berkurang dan mendapatkan insight yang lebih baik dalam melihat suatu persoalan, sehingga membuat fikiran lebih positif, perasaan lebih bersemangat dan termotivasi. Hal ini sangat membantu klien dalam menghadapi berbagai masalah dengan lebih positif. Semua klien mempunyai keinginan untuk merekomendasikan layanan konseling online kepada kerabat, rekan kerja dan sahabat mereka. Lima (5) klien tetap ingin melanjutkan sesi konsultasi melalui online dan empat (4 klien) lebih tertarik untuk melakukan sesi konseling secara tatap muka. Keefektifan konseling online dapat dilihat dari perolehan nilai score yang tinggi pada post-test layanan konseling yang diberikan kepada semua klien. Hal ini menunjukkan bahwa hasil konseling online sangat efektif.
\end{abstract}

Kata Kunci: Efektifitas Counseling Online; Kecemasan; Mahasiswa

\begin{abstract}
Counseling is one of solutions to reduce stress during Covid-19 pandemic. It is a process which may help individuals overcome various developmental barriers of their personal abilities. Online counseling is a mental health service that can relieve anxiety and confusion during Covid-19 pandemic in which social and physical distancing rules apply. This research was aimed at finding out the effectiveness of online counseling to students during the pandemic. It is used a qualitative design by explorative approach. The number of respondents in this research were nine students who experiencing anxiety during the Covid-19 pandemic. The research finding showed that online counseling was considered to be effective because it helped to reduce anxiety and worry occurred. The clients felt cognitively, behaviorally, and emotionally better changes even though they did not get counseling face to face. Besides, having got in the counseling session they felt more relaxed, calm and had better insight in solving issues, the anxiety and worry diminished as well, so they acquired positive thought, excited feeling and were motivated. This is very helpful for the clients in dealing with problems more positively. Moreover, they desired to recommend the online counseling to their relatives, work colleagues, and friends. The research result showed that five clients decided to continue the online counseling while the rests were interested in having face to face counseling. The effectiveness of the online counseling could be seen from high post test score obtained by the clients. Therefore, it could be concluded that online counseling was effective.
\end{abstract}

Keywords: The Effectiveness of Online Counseling; Anxiety; Students

How to Cite: Junita, N. \& Adyani, L. (2021), Efektifitas Konseling Online Pada Mahasiswa Selama Pandemi Covid-19, Jurnal Diversita, 7 (2): 168-174. 


\section{PENDAHULUAN}

Penyebaran virus Corona yang begitu cepat terjadi di seluruh dunia membuat kita harus belajar menerima situasi ini dengan ikhlas, karena perubahan yang terjadi berdampak terhadap berbagai sektor seperti ekonomi, teknologi, politik dan pendidikan. Perubahan ini mengharuskan masyarakat mempersiapkan diri dan merespon dengan cepat hal hal baru yang terkaitan dengan sikap serta tindakan, seperti hak pendidikan peserta didik agar tetap dapat belajar.

Hal ini ditanggapi dengan cepat oleh Kemendikbud, dengan membuat kebijakan belajar dari rumah melalui pembelajaran daring tanpa tatap muka secara langsung yang diterapkan di semua level Pendidikan dari sekolah dasar hingga perguruan tinggi yang dilakukan secara online. Pembelajaran secara daring menyebabkan mahasiswa perlu penyesuaian diri untuk beradaptasi secara cepat.

Berdasarkan wawancara (Konseling online) yang dilakukan pada beberapa mahasiswa melalui media whatsapp mengenai keadaan mereka selama pembelajaran daring dari rumah, yaitu mahasiswa dituntut untuk belajar online sesuai jadwal, mengerjakan tugas kuliah, dan semua aktivitas itu dilakukan dengan menggunakan handphone atau laptop. Mahasiswa berharap dengan adanya kuliah daring dari rumah, mereka mendapat dukungan dari keluarga, namun apa yang mereka harapkan tidak terjadi.

Mahasiswa merasa keluarga belum memahami kondisi yang mereka alami, terkait sistem pembelajaran online yang mereka jalani. Selama pembelajaran daring, orang tua menganggap anak bukan sedang kuliah, melainkan melakukan kegiatan yang tidak penting karena selalu memegang handphone. elain itu kebanyakan orang tua juga memiliki tuntutan agar anak beraktivitas secara normal ketika berada dirumah sehingga kondisi ini menimbulkan stress pada mahasiswa.

Stres merupakan reaksi atau respon tubuh terhadap penyebab (stressor) yang menimbulkan tekanan bagi individu (Hawari, 2004). Pandemi covid-19 menjadi pemicu stress yang bukan hanya dirasakan oleh mahasiswa saja, tetapi dirasakan juga oleh seluruh lapisan masyarakat Indonesia. Berdasarkan hal tersebut maka konseling menjadi salah satu alternatif untuk membantu mengurangi stres selama pandemi Covid 19. Konseling adalah proses membantu individu mengatasi tekanan dan permasalahan yang dihadapi dengan mengoptimalkan potensi diri.

Penggunaan internet sebagai media untuk konseling sudah mulai banyak dilakukan, bahkan internet bisa digunakan sebagai sarana penting dalam memberikan layanan kesehatan mental kepada kaum muda (King et al., 2006). Dengan situasi pandemik saat ini, aturan sosial dan physical distancing diberlakukan, sehingga penggunaan konseling online menjadi solusi yang patut dicoba.

Beberapa penelitian mengenai efektivitas konseling online sudah pernah dilakukan sebelumnya oleh Fitri, Neviryani, dan Ifdil (2016) yang melihat penggunaan konseling online dalam meningkatkan motivasi belajar siswa. Selain itu, penelitian dari Hernawati, 
Sugiarto, Purwanto, dan Awalya (2018) mengkonfirmasi bahwa cyber counseling efektif dalam meningkatkan pemahaman mahasiswa dalam bidang statistik.

Berdasarkan beberapa hasil penelitian yang sudah dijelaskan diatas dapat disimpulkan bahwa konseling online efektif digunakan untuk meningkatkan pemahaman dalam bidang pendidikan. Namun, efektivitas konseling online belum dilihat untuk penggunaan dalam mengurangi kecemasan yang diakibatkan oleh pandemic Covid-19 yang sedang terjadi saat ini. Sehingga dari fenomena yang telah dijabarkan tersebut, peneliti ingin melihat bagaimana efektivitas Konseling Online Selama Pandemi Covid-19 Pada Mahasiswa.

\section{METODE PENELITIAN}

Penelitian ini menggunakan metode kualititatif dengan pendekatan eksploratif untuk memahami bagaimana keefektifan konseling online. Pendekatan kualitatif merupakan pendekaan dengan menelusuri data dan informasi penelitian yang terjadi dalam kondisi apa adanya dan terjadi secara alamiah sesuai dengan ide atau fokus penelitian (Creswell, 2015). Sedangkan metode eksploratif adalah upaya pencarian (mengeskplorasi) data primer yang komperhensif pada partisipan penelitian yang tepat sasaran.

Dengan model disain ini diharapkan akan tergali informasi mengenai keefektifan konseling online pada mahasiswa selama pandemic Covid-19. Subjek penelitian ini disebut sebagai partisipan atau informan, yaitu pemberi informasi terkait permasalahan dalam penelitian. Adapun yang menjadi informan dalam penelitian ini adalah mahasiswa yang mengalami kecemasan selama pandemic Covid-19.

Tehnik pengumpulan data dilakukan secara online dengan menggunakan media whatsapp sehingga siapapun bisa mengakses layanan ini. Klien yang telah menyelesaikan sesi konseling online diberikan link evaluasi untuk melihat keefektifan proses konseling online. Data hasil konseling kemudian dianalisis secara kualitatif dan kuantitatif untuk melihat sejauh mana konseling online dapat membantu klien dalam mengatasi kecemasannya selama masa pandemic covid-19.

Teknik analisa yang dilakukan dalam penelitian ini mengikuti beberapa langkah sebagai berikut.

1. Mengolah data dan menginterpretasikan data untuk dianalisis. Langkah ini melibatkan transkip dari proses konseling, wawancara, menscanning materi, memilah dan mengelompokkan data yang diperoleh sesuai dengan sumber informasi.

2. Membaca keseluruhan data. Dalam tahap ini, meliputi kegiatan menulis catatan-catatan khusus atau gagasangagasan umum tentang data yang diperoleh.

3. Menganalisis lebih detail dengan melakukan pengkodingan. Coding dalam penelitian ini adalah dengan menyamakan kode-kode yang muncul selama proses analisis data dengan data penelitian

4. Menerapkan proses koding sehingga dapat mendeskripsikan setting, kategori, serta tema-tema sehingga dapat dianalisis. 
5. Menunjukkan hasil deskripsi dan tema-tema untuk disajikan kembali dalam bentuk narasi/laporan kualitatif. Pendekatan naratif ini meliputi penjelasan mengenai kronologis, tema, dan keterkaitan antar tema.

6. Menginterpretasi atau memaknai data. Interpretasi berupa makna yang berasal dari perbandingan anatara hasil penelitian dengan informasi yang berasal dari literatur atau teori.

\section{HASIL DAN PEMBAHASAN}

Hasil penelitian menujukan bahwa pelayanan konseling online yang diberikan oleh counselor selama sesi konseling sangat memuaskan bagi semua klien. Hal ini berdasarkan laporan yang diberikan oleh klien setelah sesi konseling dan berdasarkan data kepuasan layanan konseling online.

Setelah sesi konseling klien merasa lebih lega, lebih tenang, kecemasan dan kekhawatiran berkurang dan mendapatkan insight yang lebih baik dalam melihat suatu persoalan, sehingga membuat fikiran lebih positif, perasaan lebih bersemangat dan termotivasi. Hal ini sangat membantu klien dalam menghadapi berbagai masalah dengan lebih positif.

Selain itu semua klien mempunyai keinginan untuk merekomendasikan layanan konseling online kepada kerabat, rekan kerja dan sahabat mereka. Hasil penelitian ini menunjukan juga bahwa 5 klien tetap ingin melanjutkan sesi konsultasi melalui online dan 4 klien lebih tertarik untuk melakukan sesi konseling secara tatap muka.
Selain itu efektifitas konseling online menjadi efektif karena proses administrasi pelayanan konseling yang tertib seperti melakukan pendataan awal terhadap permasalahan klien, memilih konselor yang sesuai dengan permasalahan klien, selanjutnya klien akan menghubungi konselor atau konselor yang akan menghubungi klien. Hal ini disesuaikan dengan kesepakatan yang dibuat oleh bagian admin setelah melakukan konfirmasi dengan konselor yang dituju.

Selanjutnya klien melakukan sesi konseling dengan konselor yang dirujuk oleh bagian admin. Setelah proses sesi konseling berakkhir, konselor akan melaporkan kembali hal tersebut ke bagian admin. Selanjutnya admin akan menghubungi klien kembali untuk meminta klien mengisi form kepuasan layanan konseling online.

Layanan konseling online ini menjadi efektif, karena melalui beberapa proses tahapan yaitu Build up Rapport, Identifikasi dan penilaian masalah, memfasilitasi perubahan counseling dengan membangun Resources klien, dan evaluasi dan terminasi.

Build up Rapport yaitu membangun hubungan awal yang diawali dengan sapaan yang ramah, kata kata yang santun, yang membuat klien merasa nyaman seperti assalamualaikum, bagaimana kabar nya, sehingga terbangun suatu kepercayaan (trust) terhadap layanan yang diberikan. Tahapan pertama ini sangat penting untuk keberlangsungan sesi konseling, karena ditahapan ini klien akan memberikan penilaian terhadap sesi konseing yang akan dijalaninya bersama konselor. 
Tahapan kedua yaitu melakukan identifikasi dan penilaian masalah. Konselor memulai dengan memberikan inform consent kepada klien yaitu dengan menjelaskan prosedur pelaksanaan selama proses konseling, seperti berapa lama waktu persesi yang kan dihabiskan, dan apa saja tahapan yang akan dilakukan, yang perlu dilakukan.

Setelah klien faham, dilanjutkan dengan menggali informasi yang dapat diawali dengan melakukan pertanyaan pertanyaan terbuka seperti hal apa yang sangat mengganggu perasaan klien saat ini, jika diangka kan, di level mana keberadan perasaan yang tidak nyaman tersebut.

jika permasalahan yang mengganggu perasaan klien sangat banyak, maka konselor akan meminta klien untuk membuat daftar hal hal yang paling mengganggu perasaannya lalu meminta kepada klien untuk mengurutkannya dari yang paling mengganggu hingga yang paling rendah gangguannya.

Hal ini penting ditanyakan diawal sebagai indikator bagi konselor dalam melihat perubahan sebelum dan sesudah melakukan konseling dan juga membantu klien untuk mengidentifikasi perasaaan yang dirasakannya.

Tahap ketiga yaitu memfasilitasi perubahan konseling dengan membangun resources klien. Pada tahapan ini konselor berperan dalam membantu klien melihat potensi yang mereka miliki, membangun kesadaran dalam diri klien, melihat coping yang klien lakukan ketika berhadapan dengan kondisi yang sulit sehingga membantu klien mendapatkan insight yang baru dalam melihat berbagai persoalan secara positif.
Tahap terakhir yaitu, konselor melakukan evaluasi dan terminasi. Konselor merangkum semua proses konseling lalu melakukan affirmasi kembali kepada klien hal hal yang mengganggu perasaannya diawal dan bagaimana perasaannya saat ini setelah proses konseling dan menyimpulkan.

Berdasarkan data yang diperoleh dari hasil penelitian, menunjukkan bahwa konseling online yang dilakukan dimasa pandemik covid-19 berjalan dengan efektif.

Kegiatan konseling online dimulai dengan beberapa tahapan yaitu mulai dari sosialisasi secara online, pendaftaran klien melalui operator yang ditunjuk, lalu operator yang akan memfasilitasi klien untuk mengikuti sesi konseling, dan sebelum sesi konseling dilakukan operator menentukan kesepakatan waktu konseling dan konselor yang akan dirujuk.

Kondisi psikologis klien yang mengalami kecemasan, ketakutan dan bingung dengan kondisi psikologis yang dihadapi di masa covid-19, terlihat dari hasil pre-test dengan score yang tinggi. Kemudian klien mulai mengikuti proses sesi konseling online yang diawali dengan membangun Rapport.

Build up Rappport (membangun hubungan) menjadi Langkah awal untuk membangun kepercayaan (trust), agar saling mengenal dan terjalin kedekatan sehingga memudahkan tahap selanjutnya. (Namora, 2013).

Willis (2009) juga menyatakan bahwa harus terbentuknya a working relationship yaitu hubungan yang berfungsi, bermakna dan berguna dalam proses konseling. 
Langkah berikutnya adalah melakukan identifikasi dan penilaian masalah. Klien diminta memperkenalkan diri dan menjelaskan alasan ingin melakukan konseling online. Klien juga diminta menjelaskan masalah yang sedang dihadapi khususnya mengenai kecemasannya tentang situasi covid -19 yang masih berlangsung dan berita hoax yang bermunculan di berbagai media social.

Isu lainnya yang yang menjadi pembicaraan klien mengenai keluarga, orang tua, dan pembelajaran daring yang dilakukan dirumah. Pada tahap ini konselor mampu memahami masalah klien dengan baik, terlihat dari hasil post test menunjukkan bahwa konselor mampu menangkap masalah utama klien dengan baik, sehingga klien merasa nyaman dan percaya kepada konselor, hal ini ditunjukan oleh kesembilan klien. Enam klien menjawab sesuai dan tiga lainnya menjawab sangat sesuai. Pengungkapan masalah klien perlu diidentifikasi secara cermat.

Setelah menemukan masalah utama klien, konselor memfasilitasi perubahan konseling dengan memikirkan alternatif pendekatan yang sesuai dengan permasalahan yang dialami klien. Konselor juga perlu memperhatikan teknik pendekatan dan strategi yang tidak bertentangan dengan nilai - nilai yang terdapat pada diri klien, untuk menghindari klien menarik diri dan menolak dalam proses konseling. Dalam penelitian ini konselor menggunakan pendekatan psikologis yang sesuai dengan kebutuhan klien.

Hasil konseling menunjukkan bahwa ada perubahan yang dirasakan oleh klien.
Setelah melakukan konseling online klien lebih mengerti masalah yang terjadi dengan dirinya, mampu memahami gejala psikologis yang muncul akibat dari masalah tersebut.

Klien mampu menemukan solusi dalam memecahkan masalahnya sendiri dengan menggunakan coping yang tepat. Hal in sejalan dengan pendekatan Client Centered yang memandang kepribadian manusia secara positif. Rogers menyatakan bahwa manusia pada dasarnya kooperatif dan konstruktif sehingga dapat dipercaya. Setiap individu pasti memiliki kemampuan dalam mencapai kondisi psikologis yang sehat. (Corey, 2009).

Keefektifan konseling online dapat dilihat dari perolehan nilai score yang tinggi pada post-test yang diberikan oleh kesembilan klien. Hal ini menunjukkan bahwa konseling online yang dilakukan dalam beberapa sesi pertemuan konseling sangat baik.

Pengalaman klien selama mengikuti sesi konseling online memotivasi klien untuk merekomendasikan layananan ini ke teman dan keluarga. Hal ini menunjukkan klien merasa konseling online yang dilakukan sangat efektif dan positif untuk menyelesaikan masalah agar tidak berdampak jangka panjang. Kondisi ini ditunjukan dengan menurunnya gejala psikologis yang dirasakan oleh semua klien.

Klien merasa lebih siap secara mental dalam menghadapi dan beradaptasi dengan situasi covid. Mereka merasa kecemasannya berkurang, merasa lebih tenang dan terus mengembangkan positif thingking dalam menjalani kehidupannya. 
Jurnal Diversita, 7 (2) Desember 2021: 168-174.

\section{SIMPULAN}

Penelitian terhadap efektifitas konseling online pada mahasiswa online selama pandemic covid-19 dianggap efektif karena dapat membantu menurunkan kecemasan dan kekhawatiran yang muncul. Klien merasakan perubahan yang lebih baik walaupun tidak melakukan konseling secara tatap muka.

Pada masa pandemic covid-19, konseling online menjadi kebutuhan yang perlu difasilitasi oleh berbagai Lembaga terkait, karena sangat membantu klien dalam mengatasi permasalah psikologis yang dialami selama masa pandemik covid-19.

Kebanyakan klien merasakan keresahan yang diakibatkan oleh adanya Covid-19, baik berkaitan dengan informasi yang didapat dan proses pembelajaran daring yang dilakukan oleh mereka yang masih mahasiswa. Dengan adanya pelayanan konseling online, mereka memiliki tempat yang tempat dan orang yang tepat untuk berbagi masalah yang mereka rasakan, sehingga membuat klien merasa puas dan termotivasi untuk merekomendasikan pelayanan ini kepada kerabatnya yang lain.

Dukungan keluarga menjadi penting agar proses pembelajaran daring menjadi bermakna. Begitupun dukungan dari kampus yang memfasilitasi proses pelaksanaan pembelajaran daring dan pemerintah yang menyedia support dalam bentuk quota internet bagi pelaksanaan kuliah daring.

\section{DAFTAR PUSTAKA}

Corey, G. (2009). Teori dan Praktek Konseling dan Psikoterapi. Rafika Aditama.
Creswell, J. W. (2015). Penelitian Kualitatif $\mathcal{E}$ Desain Riset. Pustaka Belajar.

Fitri, E., Ifdil, I., \& S., N. (2016). Efektivitas layanan informasi dengan menggunakan metode blended learning untuk meningkatkan motivasi belajar. Jurnal Psikologi Pendidikan Dan Konseling: Jurnal Kajian Psikologi Pendidikan Dan Bimbingan Konseling, $\quad 2(2), \quad 84$. https://doi.org/10.26858/jpkk.v2i2.2250

Hawari, D. (2004). Manajemen Stress, Cemas, dan Depresi. Balai Penerbit Fakultas Kedokteran Universitas Indonesia.

Hernawati, L., Sugiarto, D., Purwanto, E., \& Awalya, A. (2018). The Effectiveness of Cyber Counseling Service to Enhance Student Performance in Statistics. 247(Iset), 302306. https://doi.org/10.2991/iset-18.2018.63

King, R., Bambling, M., Reid, W., \& Thomas, I. (2006). Telephone and online counselling for young people: A naturalistic comparison of session outcome, session impact and therapeutic alliance. Counselling and Psychotherapy Research, 6(3), 175-181. https://doi.org/10.108o/1473314060o874084

Namora, L. L. (2013). Memahami Dasar-dasar Konseling dalam Teori dan Praktik. Kencana Prenada Media Grup.

Willis, S. S. (2009). Konseling Keluarga. Alfabeta. 